\title{
PARENTING BAGI ORANG TUA MUDA DI PUSAT PEMBELAJARAN KELUARGA SURABAYA PERSPEKTIF ABDULLAH NASHIH 'ULWAN
}

\author{
`Azmatul Husniyah
}

Rumah Belajar Amaryllis Perumahan Pondok Nirwana

Anggaswangi Cluster Amaryllis Blok M1 Sukodono Sidoarjo.

Email: azmah@gmail.com

\begin{abstract}
In this information and technology era, families face many challenges, especially in terms of childcare. The many social issues related to the family, especially the role of parents, make government institutions take the initiative to build family resilience by providing parents with knowledge about parenting. This article intends to highlight parenting activities for young parents beld by the Surabaya City Government through the Puspaga (Family Learning Center) program. This program is intended to increase the knowledge of young parents about parenting towards children and make them aware of the importance of knowledge about parenting as a provision to foster harmonious families. Data was collected using interview techniques with participants and Puspaga administrators and documentation techniques. To assess this practice, the author uses child education theory according to Abdulloh Nashih 'Ulwa who emphasizes education in the fields of faith, morals, physical, psychological, resourceful, and social. The parenting program for young parents held by Puspaga is compatible with the concepts of Islamic education according to Abdullah Nashib 'Ulwa.
\end{abstract}

Keywords: Parenting Young Parents, PUSPAGA, Islamic Parenting.

Abstrak: Tujuan utama dari penelitian ini adalah untuk mengungkapkan bahwa pendidikan parenting yang didapat oleh pemuda sebelum menikah atau di awal pernikahan dapat menyadarkan orang tua akan pentingnya pengetahuan ini terhadap tiap langkah perkembangan anak. Penelitian ini menggunakan metode penelitian kualitatif dengan melakukan wawancara dan dokumentasi dengan peserta dan stake holder di PUSPAGA Surabaya. Subyek penelitiannya adalah orang tua muda yang mengikuti training parenting di Pusat pembelajaran Keluarga (PUSPAGA) Surabaya. Dalam hal ini peneliti memakai pendidikan anak menurut Dr. Abdulloh Nashih 'Ulwa. Teknik pengumpulan data dilakukan dengan cara observasi, wawancara dan dokumentasi, dan hasinya adalah bahwa pengetahuan tentang pola pengasuhan anak atau parenting di Pusat Pembelajaran Keluarga di Surabaya yang dimiliki orang tua muda sebelum atau sesudah menikah merupakan bagian dengan parenting perspektif islam menurut Dr. Abdullah Nashih 'Ulwan yaitu pendidikan keimanan, moral, fisik, psikologis, akal, fisik dan sosial.

AL-HUKAMA

The Indonesian Journal of Islamic Family Law Volume 09, Nomor 01, Juni 2019; ISSN:2089-7480 
Kata Kunci: Parenting Orang Tua Muda, PUSPAGA, Parenting Islam.

\section{Pendahuluan}

Revolusi mental yang digaungkan oleh pemerintah periode ini memberikan perhatian yang besar terhadap problem kesehatan mental masyarakat, kesehatan mental memiliki beragam makna dengan pemahaman dasar bahwa kondisi individu yang tentram dan dalam keadaan tenang, sehingga mampu untuk menjalani keseharian hidup dengan baik dan dapat menghargai orang lain karena seragam kebutuhan fisik, sosial, psikis dan pendidikannya tercukupi.

Pemuda dalam proses menuju kedewasaan menurut UU nomor 40 tahun 2009 pasal 1 tentang Kepemudaan adalah warga negara Indonesia dengan rentang usia 16-30 tahun. Sedangkan istilah pemuda dalam ilmu psikologi istilah pemuda dikenal dengan dewasa awal. Masa dewasa awal adalah masa dimana seseorang dianggap mampu menerima peran sosial dalam masyarakat dengan mulai membangun relasi dengan orang di sekitarnya dan kondisi fisik yang telah sempurna fungsinyal. Data statistik berdasarkan proyeksi penduduk di Jawa Timur pada tahun 2010-2020 menunjukkan bahwa jumlah penduduk Jawa Timur tahun 2017 adalah sekitar 39,29 juta jiwa, dan 22,73 persen (8,93 juta jiwa) diantaranya berusia 16-30 tahun2. Sementara itu berdasar data statistik BAPPENAS persentase pemuda laki-laki dengan status belum menikah (66,93 persen) adalah sekitar dua kalinya persentase pemuda laki-laki yang sudah menikah (32,22 persen). Sebaliknya persentase pemuda perempuan yang berstatus belum menikah (41,12 persen) lebih rendah daripada persentase pemuda perempuan yang berstatus menikah (56,84 persen). Perbedaan pola status pernenikahan antara laki-laki dan perempuan tersebut menunjukkan bahwa perempuan pada umumnya menikah di usia lebih muda dibanding laki-laki3.

1 John W. Santrock, Life -Span Development, (Jakarta: Erlangga, 2012), 28.

2 Badan Statistik Provinsi Jawa Timur, Statistik Pemuda Provinsi jawa Timur 2017, BPS Jawa

Timur, 15.

3 Sub Direktorat Statistik dan Pendidikan Kesejahteraan Sosial, Statistik Pemuda Indonesia, (Jakarta: Badan Pusat Statistik), 29. 
Parenting atau disebut pola pengasuhan yaitu suatu bentuk usaha yang dilakukan orang tua pada anak, agar anak dapat tumbuh menjadi pribadi yang unggul4, sebenarnya pola pengasuhan membutuhkan tata cara dan tata cara tertentu, sehingga tidak sekedar pengetahuan common sanse yang bisa langsung difahami secara langsung, bukan juga pengetahuan yang akan cepat difahami dengan seiring berjalannya waktu5, sebagai ilmu tentang cara pengasuhan anak dalam arti sederhana dengan jalan melakukan tanggung jawab dan tugas demi mendampingi tumbuh kembang anak fisik6, meliputi, perawatan tubuh anak, pemberian makanan dan memperhatikan kesehatan anak dalam masa tumbuh kembangnya, dan mental meliputi, penanaman nilai moral dan sifat yag baik, mengembangkan kreatifitas dan bakat anak, dan perkembangan sosial meliputi cara menyapa orang lain, menghargai dan menghormati jasa orang lain.

Bentuk pola pengasuhan, sikap, dan praktik yang dilakukan orang tua itu sebagiannya dibentuk oleh pengalaman orang tua itu sendiri (termasuk dari masa kecil mereka) dan keadaan, harapan dan praktik yang dipelajari dari orang lain, seperti keluarga, teman, dan jejaring sosial lainnya, dan kepercayaan yang diambil melalui sistem budaya dan sosial di sekelilingnya. Parenting juga dibentuk dari ketersediaan dukungan komunitas yang ada dan ketersediaan layanan yang mendukung7.

Orang tua muda sebagai role model adalah orang tua yang memberi inspirasi dan dorongan kepada anak untuk berjuang demi sesuatu yang dicita-citakan, membangkitkan potensi maksimal anak dan mampu melihat hal yang terbaik yang ada di dalam diri anak8.

4 Melly Kiong, Mindful Parenting, (Jakarta: Kemendikbud, 2015), 1.

5 Hassan Syamsi Basya, kayfa Turabbi Abna aka fi hadha al-Zaman, terj. Zaenal Arifin "Mendidik. Anak Zaman Kita” (Jakarta: Zaman, 2011), 10.

6 Z. Hayati, Anak Saya Tidak Nakal, (Yogyakarta: PT. Bintang Pustaka, 2010), 11. 7 Vivian L. Gadsden, Morgan Ford and Heather Briener, Parenting Matter Supporting parent of children age 0-8, (Washington, DC: National Academies Press, T.T), 22.

8 Bashir, S. 2014. Teacher as A Role Model and Its Impact on the Life of Female Students. International Journal of Research -Granthaalayah. Shakila ,Vol.1, August,2014, 34. 
Role model bukan hanya orang tua, lingkungan masyarakat, saudara dan teman juga bisa dikatakan demikian dengan pengertian di atas.

Pendidikan parenting di kalangan orang tua muda belum banyak dilakukan, parenting ini baru digalakkan di PAUD, TK dan $\mathrm{SD}$, pasa saat itu pemuda yang mengikuti parenting telah menjadi orang tua dan memiliki anak, hal tersebut kebingungan dan ketidaktahuan orang tua muda dalam pengasuhan fisik dan mental. Alih alih menanamkan moral, pengetahuan sosial anak, bagaimana cara mengganti popok atau memandikan saja masih minim, belum lagi tata cara dan masalah yang muncul saat menyusui, mengahadapi masalah demam, tangisan yang tak kunjung reda, belum lagi kurangnya campur tangan suami dalam pengasuhan. Tentu hal ini akan menjadi beban mental pemuda yang menjadi calon ibu. Kondisi mental ibu yang kurang sehat dapat berakibat kurang baik dalam memberikan pengasuhan pada anak. Berdasar data statitik di atas, dominannya jumlah pemuda yang telah menikah terutama yang berjenis kelamin wanita, membuat pendidikan parenting dirasa sangat perlu disediakan untuk meningkatkan kesehatan mental dan kesiapan orang tua muda menjadi role model bagi anak.

1. Pengertian Parenting Perspektif Pendidikan Islam

Menurut An-Nahwawi, kata tarbiyah berasal dari tiga kata, yaitu raba-yarbu yang artinya bertambah dan berkembang, rabiya-yarba dengan wazan khafiya-yakhfa yang berarti tumbuh dan berkembang, rabba-yarbu dengan wazan madda-yamuddu yang berarti memperbaiki, mengurusi, menjaga dan memperhatikan9.

Parenting dalam konsep pendidikan anak dalam islam memiliki pengertian, yakni proses penanaman demi menyampaikan beberapa hal hingga mencapai sempurna. Mengembangkan kekuatan dan potensi individu dalam segi religiusitas, akal dan fisiknya, dengan muatan yang seimbang10.

2. Dasar Parenting Perspektif Pendidikan Islam

9 Abdurrahman An-Nahwawi, Pendidikan Islam di Rumah, Sekolah, dan Masyarakat, (Jakarta: Gema Insani,1995), 20.

10 Muhammad Hasan Roqid, Kayfa Nurabbi Abnaana tarbiyatan S \}olibatan, vol 1, 2. 
Abdul Fattah Jalal membagi sumber pendidikan Islam menjadi dua yaitu11:

a. Sumber Ilahi

b. Sumber Insaniyah

Di sisi lain dasar parenting pendidikan islam menurut Hasan Langgulung, ada 6 (enam), yaitu:12

Al-Quran, Hadis, Asar Sahabat, kemaslahatan Sosial, nilai-nilai dan kebiasaan sosial, dan yang terakhir bersumber dari pemikir-pemikir Islam yang tertuang dalam literatur.

3. Tujuan Parenting Perspektif Pendidikan Islam

Athiyah Al-Abrasyi menuturkan ada lima tujuan pendidikan Islam secara umum, yaitu13:

a. Membantu pembentukan akhlak yang mulia

b. Mempersiapkan untuk kehidupan dunia akhirat

c. Membentuk pribadi yang utuh, sehat jasmani dan ruhani.

d. Menumbuhkan ruh ilmiyah, sehingga memungkinkan murid mengkaji ilmu semata untuk ilmu itu sendiri.

e. Menyiapkan murid agar mempunyai profesi tertentu sehingga dapat melaksanakan tugas dunia dengan baik, atau singkatnya persiapan untuk mencari rizki.

4. Ciri-Ciri Parenting Perspektif Pendidikan Islam14

Anak adalah amanah Allah bagi setiap orang tua. Ia dititipkan kepada kita untuk diasuh, dididik, dan dibimbing menjadi anak yang $s\}$ alih dan $s\}$ alihah. Dijadikan sebagai bagian dari komunitas muslim, penerus risalah Islam yang dibawa oleh Rasulullah Muhammad saw yang akan sangat bangga dengan umatnya yang kuat dan banyak. Anak adalah anugerah terindah dari Allah swt bagi setiap orang tua. Kehadirannya begitu dinantikan. Karena anak bisa menjadi penghibur di kala duka,

11 Abdul Fatah Jalal, Asas-Asas Pendidikan Islam, (Bandung: Diponegoro, 1988), 143.

12 Hasan Langgulung, Beberapa Pemikiran tentang Pendidikan Islam, (Jakarta: Pustaka Al-Husna, 1986), 32.

13 Athiyah al-Abrasyi, Al-Tarbiyah al-Islamiyah, terj. Abdullah Zaki al-Kaaf, Dasar Dasar Pokok Pendidikan Islam, (Jakarta: Bulan Bintang, 1970), 2.

14 Abdullah Nashih Ulwan, Tarbiyatul Aulad fi al-Islam, ( Mesir: Dar salam, T.t). 201. 
dan mampu menjadi penumbuh semangat kerja keras bagi orang tuanya. Walau terkadang juga, anak bisa menjadi penghalang kesuksesan segala aktivitas orang tua dan mengganggu waktu istirahat. Sedangkan Dr. Abdullah Nashih Ulwan mengatakan bahwa anak adalah anugerah termahal bagi setiap orang tua. Sulit ketika diminta, dan tidak bisa ditolak ketika Allah swt menghendaki kelahirannya. Kehadirannya adalah sebuah rahasia Sang Pencipta, walaupun banyak orang berhasil merencanakan kapan anaknya harus lahir dan kapan tidak melahirkan anak. Selain sebagai anugerah dari Yang Maha Kuasa, Allah Sang Pencipta, anak diberikan kepada orang tua sebagai amanah untuk dipelihara, dididik, dan dibina menjadi anak-anak yang berkualitas, memiliki kekuatan dan ketahanan sebagai bekal mengarungi hidup di masa dewasanya.

Dengan demikian dapat disimpulkan bahwa anak s\}alih menurut pandangan Dr. Abdullah Nashih Ulwan adalah anak yang taat dan bersungguh-sungguh dalam menjalankan perintah-perintah Allah dan menjauhi larangan-larangan-Nya dengan bersumber pada nilai-nilai Islami, serta menjadikan Islam sebagai agama, Al-Quran sebagai imam dan Rasulullah saw. Sebagai pemimpin dan tauladan. Dr. Abdullah menegaskan bahwa hanya ada satu cara agar anak menjadi permata hati dambaan bagi setiap orang tua, yaitu melalui pendidikan yang bersumber dari nilai-nilai Islam. Islam telah memberikan dasar-dasar konsep pendidikan dan pembinaan anak, bahkan sejak masih dalam kandungan. Jika anak sejak dini telah mendapatkan pendidikan Islam, maka akan tumbuh menjadi insan yang mencintai Allah dan Rasul-Nya serta berbakti kepada orang tuanya. Adapun ciri-ciri anak salih yaitu:

a. Beriman dan bertaqwa kepada Allah swt dan hari Akhir.

b. Mencintai Rasulullah saw dan ahli baitnya.

c. Meneladani sepak terjang para sahabat.

d. Berbuat baik kepada orang tua (Birrul walidain).

e. Amar makruf nabi munkar.

f. Mendirikan sholat, puasa, membayar zakat, menunaikan haji bila mampu.

g. Bersabar dalam menghadapi cobaan kehidupan. 
h. Tidak bersikap sombong, masa bodoh, atau acuh tak acuh.

i. Selalu bertutur sopan dan bersikap santun terhadap setiap orang.

Namun ternyata Dr. Abdullah Nashih Ulwan tidak berhenti ada pendidikan usia dini, tetapi Dr. Abdullah Nashih Ulwan mengatakan bahwa pendidikan secara Islami haruslah diberikan kepada anak didik sampai dia mampu hidup di tengah-tengah masyarakat sebagai insan yang bertakwa dan berakhlaq mulia. Dr. Abdullah Nashih Ulwan pun juga membagi pendidikan dalam beberapa aspek, yaitu15:

a. Tanggung jawab pendidikan iman, meliputi:

b. Tanggung Jawab Pendidikan Moral.

c. Tanggung Jawab Pendidikan Fisik

d. Tanggung jawab pendidikan akal

e. Tanggung jawab pendidikan psikologis, diantaranya dengan cara:

f. Tanggung Jawab Pendidikan Sosial

5. Metode Parenting Perspektif Pendidikan Islam

Dr. Abdullah Nashih Ulwan mengatakan bahwa metode parenting anak meliputi16 :

a. Pendidikan dengan Keteladanan

Keteladanan dalam parenting merupakan metode yang berpengaruh dan terbukti paling berhasil dalam mempersiapkan dan membentuk aspek moral, spiritual, dan etos sosial anak. Mengingat orang tua adalah seorang figur terbaik dalam pandangan anak, yang tindak tanduk dan sopan santunnya, disadari atau tidak, akan ditiru oleh mereka. Bahkan bentuk perkataan, perbuatan dan tingkah lakunya akan senantiasa tertanam dalam kepribadian anak. Oleh karena itu, masalah keteladanan menjadi faktor penting dalam menentukan baik buruknya anak. Jika pendidik jujur, dapat dipercaya, berakhlak mulia, berani dan menjauhkan diri dari perbuatan yang bertentangan dengan agama, maka si anak akan tumbuh dalam kejujuran, terbentuk dengan

15 Abdullah Nashih Ulwan, Tarbiyatul Aulad fi al-Islam,157.

16 Abdullah Nashih Ulwan, Tarbiyatul Aulad fi al-Islam, 202. 
akhlak mulia, berani dan menjauhkan diri dari perbuatanperbuatan yang bertentangan dengan agama.

b. Parenting dengan Adat Kebiasaan

Tidak ada yang menyangkal, bahwa anak akan tumbuh dengan iman yang benar, berhiaskan diri dengan etika islam,bahkan sampai pada puncak nilai-nilai spiritual yang tinggi, dan kepribadian yang utama, jika anak hidup dengan dibekali dua faktor : pendidikan islam yang utama dan lingkungan yang baik. Khusus tentang lingkungan yang baik ini, jika anak menerima pendidikan yang baik dari orang tuanya yang sholeh dan pengajarnya yang tulus, disamping tersedianya lingkungan yang baik dari teman yang s\}olih, mukmin dan tulus, maka tidak diragukan bahwa anak tersebut akan terdidik dalam keutamaan, iman dan taqwa.

c. Parenting dengan Nasihat

Termasuk metode Parenting yang cukup berhasil dalam pembentukan akidah anak dan mempersiapkannya baik secara moral, emosional maupun sosial adalah parenting dengan petuah dan memberikan nasihat-nasihat kepada anak, sebab nasihat dan petuah memiliki pengaruh yang cukup besar dalam membuka kesadaran anak tentang hakikat sesuatu, mendorong mereka menuju harkat dan martabat yang luhur, menghiasinya dengan akhlaq yang mulia, membekalinya dengan prinsip-prinsip Islam.

Menurut pendapat Dr. Abdullah Nashih Ulwan, metode Al-Qu'an dalam menyajikan nasihat dan pengajaran mempunyai ciri tersendiri, seperti tampak di bawah ini :

a) Seruan yang menyenangkan, seraya dibarengi dengan kelembutan atau upaya penolakan.

b) Metode cerita disertai dengan perumpamaan yang mengandung pelajaran dan nasihat.

c) Metode wasiat dan nasihat.

d. Parenting dengan Perhatian atau Pengawasan

Maksud parenting dengan perhatian adalah senantiasa mencurahkan perhatian penuh dan mengikuti perkembangan aspek akidah dan moral anak, mengawasi dan memperhatikan kesiapan mental dan sosial, di samping 
selalu bertanya tentang situasi pendidikan jasmani dan kemampuan ilmiyahnya. Sudah barang tentu, bahwa parenting semacam ini merupakan modal dasar yang dianggap paling kokoh dalam pembentukan manusia seutuhnya yang sempurna, yang menunaikan hak setiap orang yang memilikinya dalam kehidupan dan termotivasi untuk menunaikan tanggung jawab dan kewajiban secara sempurna. Melalui upaya tersebut akan tercipta muslim hakiki, sebagai batu pertama untuk membangun pondasi Islam yang kokoh. Sudah menjadi kesepakatan, bahwa memperhatikan dan mengawasi anak yang dilakukan oleh orang tua sebagai pengasuh, adalah asas parenting yang paling utama.

e. Parenting dengan memberikan hukuman.

Hukuman yang berbeda-beda, sesuai dengan usia, kultur, dan kedudukannya. Sebagian orang cukup dengan diberi nasihat yang lembut. Sebagian lagi cukup dengan diberi kecaman, dan sebagian lain tidak cukup hanya dengan tongkat, dan sebagian lain tidak juga meninggalkan kejahatan kecuali dengan kurungan.

Dibawah ini metode yang dipakai Islam dalam upaya memberikan hukuman kepada anak:

1) Lemah lembut dan kasih sayang adalah dasar pembenahan anak

2) Menjaga tabiat anak yang salah dalam menggunakan hukuman

3) Dalam upaya pembenahan, hendaknya dilakukan secara bertahap, dari yang paling ringan hingga yang paling keras.

Tetapi ketika Islam menetapkan hukuman dengan pukulan, Islam memberikan batasan dan persyaratan, sehingga pukulan tidak keluar dari maksud pendidikan, yaitu untuk memperbaiki dan membuat jera.

Sedangkan persyaratan memberikan hukuman pukulan adalah sebagai berikut: 
1) Pendidik tidak terburu menggunakan metode pukulan, kecuali setelah menggunakan semua metode lembut, yang mendidik dan membuat jera.

2) Pendidik tidak memukul ketika dalam keadaan sangat marah, karena dikhawatirkan menimbulkan bahaya terhadap anak.

3) Ketika memukul hendaknya menghindari anggota badan yang peka, seperti kepala, muka, dada dan perut.

4) Pukulan untuk hukuman, hendaknya tidak terlalu keras dan tidak menyakiti, pada kedua tangan atau kaki dengan tongkat yang tidak besar.

5) Tidak memukul anak, sebelum ia berusia sepuluh tahun.

6) Jika kesalahan anak adalah yang pertama kali maka hendaknya ia diberi kesempatan untuk bertaubat dari perbuatan yang telah dilakukan, memberi kesempatan untuk minta maaf, dan diberi kelapangan untuk didekati seorang penengah, tanpa memberi hukuman, tetapi mengambil janji untuk tidak mengulangi kesalahannya itu.

7) Pendidik hendaknya memukul anak dengan tangannya sendiri dan tidak menyerahkan kepada saudarasaudaranya atau teman-temannya. Sehingga tidak timbul api kebencian dan kedengkian diantara mereka.

8) Jika anak sudah menginjak usia dewasa dan pendidik melihat bahwa pukulannya itu tidak membuatnya jera, maka ia boleh menambah atau mengulanginya sampai anak itu menjadi baik. Dari sini jelaslah bahwa pendidikan Islam telah memberikan perhatian yang besar tentang hukuman, baik hukuman spiritual maupun material. Hukuman ini telah memberi batasan dan persyaratan, dan pendidik tidak boleh melanggar. Sangat bijaksana jika pendidik meletakkan hukuman pada proporsi yang sebenarnya, seperti juga meletakkan sikap ramah tamah dan lemah lembut pada tempat yang sesuai. Dan sangat dungu jika pendidik bersikap lemah lembut ketika membutuhkan kekerasan dan ketegasan atau bersikap 
keras dan tegas pada saat membutuhkan kasih sayang dan kelapangan dada.

\section{Latar Belakang Berdirinya Pusat Pembelajaran Keluarga (PUSPAGA)}

Permasalahan keluarga fenomenanya seperti gunung es, masalah yang nampak dipermukaan sangat kecil sekali. Pengaruh sosial kultural masyarakat menjadi salah satu penyebab minimnya data mengenai permasalahan keluarga. Beberapa permasalahan yang muncul dan dapat dicatat seperti : 272.794 kasus perceraian, 38,62\% anak mengalami Tindak Kekerasan dan sebagian besar dilakukan oleh orang-orang terdekat, $11.69 \%$ dari 67,9 Juta KK adalah Perempuan. Permasalahan di Bali yang terdata seperti Tahun 2017 253 anak berurusan dengan Hukum (masalah kekerasan seksual, pencurian, pelanggaran lalu lintas), Kasus Perceraian di Bali sangat tinggi (meningkat 10\% setiap tahun dan rata-rata tiap hari ada dua pasangan cerai), Laporan Kasus KDRT di Badung : Tahun 2014 : 67 kasus, Tahun 2015 : 60 kasus, Tahun $2016: 74$ kasus dan Tahun 2017 : 44 kasus.

Keluarga mengalami hambatan dalam pemecahan masalah karena kurangnya pengalaman dan kemampuan. Keluarga membutuhkan tempat untuk konsultasi dan pendampingan serta belajar sehingga kapasitas keluarga semakin optimal.

Pengasuhan memegang peran yang sangat penting dalam sebuah keluarga dan akan menentukan baik buruknya karakter seorang anak kelak. Kegagalan keluarga dalam melaksanakan tanggung jawab pengasuhan disertai lemahnya program pemerintah dalam membantu atau memberdayakan keluarga tersebut untuk mengasuh dan melindungi anak, dikhawatirkan akan menyebabkan anak berada dalam kondisi rentan dan beresiko mengalami kekerasan, eksploitasi, penelantaran, dan perlakuan salah lainnya. Oleh karena itu, Kemen PPPA telah menyiapkan program unggulan PUSPAGA untuk mengatasi masalah ini," ujar Menteri Yohana.

PUSPAGA sebagai tempat pembelajaran bertujuan untuk meningkatkan kualitas kehidupan menuju keluarga sejahtera yang dilakukan oleh tenaga profesional seperti tenaga konselor, baik psikolog atau sarjana profesi bidang psikologi, Bimbingan Konseling atau Pekerja Sosial yang telah memahami Konvensi Hak 
Anak, melalui peningkatan kapasitas orang tua keluarga yang bertanggung jawab terhadap anak dalam mengasuh dan melindungi anak dari kekerasan, eksploitasi, perlakuan salah, dan penelantaran. Hal ini merupakan salah satu unsur prioritas dalam pelaksanaan kebijakan Kabupaten/Kota Layak Anak (KLA).

PUSPAGA adalah bentuk layanan pencegahan di bawah koordinator Dinas Pemberdayaan Perempuan dan Perlindungan Anak sebagai wujud kepedulian Negara dalam meningkatkan kehidupan keluarga dan ketahanan keluarga melalui program pendidikan pengasuhan, keterampilan menjadi orangtua, keterampilan melindungi anak, kemampuan meningkatkan partisipasi anak dalam keluarga maupun penyelenggaraan program konseling bagi anak dan keluarga. Pada 2016, Kemen PPPA telah menginisiasi PUSPAGA dengan jumlah mencapai 18, yaitu di 2 provinsi dan 16 kabupaten/kota. Setiap kabupaten/kota minimal memiliki 1 (satu) PUSPAGA. "Saya sangat berharap PUSPAGA dapat segera dimanfaatkan oleh seluruh masyarakat dan keluarga yang ingin mencari solusi bagi masalah keluarga sehingga selama 24 jam kehidupan anak setiap harinya dapat terjamin pengasuhannya," tambah Menteri Yohana.

Pusat Pembelajaran Keluarga (PUSPAGA) adalah tempat pembelajaran untuk meningkatkan kualitas kehidupan keluarga yang dilakukan oleh tenaga profesional melalui peningkatan kapasitas orang tua atau keluarga atau orang yang bertanggung jawab terhadap anak dalam menjalankan tanggung jawab mengasuh dan melindungi anak. PUSPAGA didirikan di bawah naungan Menteri Pemberdayaan Perempuan dan Perlindungan Anak.

Untuk Surabaya, Peresmian PUSPAGA Surabaya pada 9 Januari 2017. Lokasi PUSPAGA Surabaya MALL PELAYANAN PUBLIK (Ex. Siola) Jl Tunjungan no. 1 - 3 lantai 2, Surabaya Prinsip dasar pelayanan puspaga adalah: One stop service, non diskriminasi, mudah dijangkau, promotif dan preventif, aman dan nyaman serta gratis.

\section{Dasar-dasar Hukum Berdirinya PUSPAGA}

1. Undang - undang Dasar 1945, Pasal 28b

Pasal 28 
Kemerdekaan berserikat dan berkumpul, menge-luarkan pikiran dengan lisan dan tulisan dan sebagainya ditetapkan dengan undang-undang.

Pasal 28B

a. Setiap orang berhak membentuk keluarga dan melanjutkan keturunan melalui perkawinan yang sah.

b. Setiap anak berhak atas kelangsungan hidup, tumbuh, dan berkembang serta berhak atas perlindungan dari kekerasan dan diskriminasi

2. Undang - undang Nomor 35 Tahun2014 Tentang Perubahan Atas UU Nomor 23 Tahun 2002 tentang Perlindungan Anak

a. bahwa Negara Kesatuan Republik Indonesia menjamin kesejahteraan tiap warga negaranya, termasuk perlindungan terhadap hak anak yang merupakan hak asasi manusia;

b. bahwa setiap anak berhak atas kelangsungan hidup, tumbuh dan berkembang serta berhak atas perlindungan dari kekerasan dan diskriminasi sebagaimana diamanatkan dalam Undang-Undang Dasar Negara Republik Indonesia Tahun 1945;

c. bahwa anak sebagai tunas, potensi, dan generasi muda penerus cita-cita perjuangan bangsa memiliki peran strategis, ciri, dan sifat khusus sehingga wajib dilindungi dari segala bentuk perlakuan tidak manusiawi yang mengakibatkan terjadinya pelanggaran hak asasi manusia;

d. bahwa dalam rangka meningkatkan perlindungan terhadap anak perlu dilakukan penyesuaian terhadap beberapa ketentuan dalam Undang-Undang Nomor 23 Tahun 2002 tentang Perlindungan Anak;

e. bahwa berdasarkan pertimbangan sebagaimana dimaksud dalam huruf a, huruf $b$, huruf $c$, dan huruf $d$ perlu membentuk Undang-Undang tentang Perubahan atas Undang-Undang Nomor 23 Tahun 2002 tentang Perlindungan Anak;

3. Undang - undang Nomor 23 Tahun 2014 tentang Pemerintahan Daerah 
a. bahwa sesuai dengan Pasal 18 ayat (7) Undang-Undang Dasar Negara Republik Indonesia Tahun 1945 susunan dan tata cara penyelenggaraan pemerintahan daerah diatur dalam Undang-Undang;

b. bahwa penyelenggaraan pemerintahan daerah diarahkan untuk mempercepat terwujudnya kesejahteraan masyarakat melalui peningkatan pelayanan, pemberdayaan, dan peran serta masyarakat, serta peningkatan daya saing daerah dengan memperhatikan prinsip demokrasi, pemerataan, keadilan, dan kekhasan suatu daerah dalam sistem Negara Kesatuan Republik Indonesia;

c. bahwa efisiensi dan efektivitas penyelenggaraan pemerintahan daerah perlu ditingkatkan dengan lebih memperhatikan aspek-aspek hubungan antara Pemerintah Pusat dengan daerah dan antardaerah, potensi dan keanekaragaman daerah, serta peluang dan tantangan persaingan global dalam kesatuan sistem penyelenggaraan pemerintahan negara;

d. bahwa Undang-Undang Nomor 32 Tahun 2004 tentang Pemerintahan Daerah tidak sesuai lagi dengan perkembangan keadaan, ketatanegaraan, dan tuntutan penyelenggaraan pemerintahan daerah sehingga perlu diganti;

e. bahwa berdasarkan pertimbangan sebagaimana dimaksud dalam huruf a, huruf $b$, huruf $c$, dan huruf $d$ perlu membentuk Undang-Undang tentang Pemerintahan Daerah;

\section{Konvensi Hak Anak}

Konvensi Hak Anak merupakan wujud nyata atas upaya perlindungan terhadap anak, agar hidup anak menjadi lebih baik. Sejak Indonesia meratifikasi Konvensi Hak Anak di Tahun 1990 banyak kemajuan yang telah ditunjukkan oleh pemerintah Indonesia dalam melaksanakan Konvensi Hak Anak. Dalam menerapkan Konvensi Hak Anak, negara peserta konvensi punya kewajiban untuk melaksanakan ketentuan dan aturan-aturannya dalam kebijakan, program dan tata laksana pemerintahannya. 
Konvensi Hak Anak merupakan sebuah perjanjian yang mengikat, yang artinya ketika disepakati oleh suatu negara, maka negara tersebut terikat pada janji-janji yang ada di dalamnya dan negara wajib untuk melaksanakannya. Konvensi Hak Anak merupakan sebuah perjanjian hukum international tentang hakhak anak. Konvensi ini secara sederhana dapat dikelompokkan kedalam 3 hal. Pertama, mengatur tentang pihak yang berkewajiban menanggung tentang hak yaitu negara. Kedua, pihak penerima hak yaitu anak-anak. Ketiga, memuat tentang bentuk-bentuk hak yang harus dijamin untuk dilindungi, dipenuhi dan ditingkatkan. Relasi antara pemegang hak dan pemangku kewajiban

5. Nawacita Presiden

6. SK Walikota Surabaya Nomor : 6830/02/HK/2017 tentang pembentukan PUSPAGA

\section{Pendidikan Parenting di Pusat Pembelajaran Keluarga Surabaya}

Kelas parenting termasuk ke dalam pendidikan orang dewasa, dimana pendidikan orang dewasa itu diperuntukkan bagi orang dewasa dalam lingkungan masyarakat, agar mereka dapat mengembangkan kemampuan, memperkaya pengetahuan, meningkatkan keterampilan dan profesi yang telah dimiliki, memperoleh cara-cara baru, serta mengubah sikap dan perilaku orang dewasa17.

Layanan kelas parenting adalah pendidikan yang diberikan kepada anggota keluarga, khususnya bagi orang tua yang memiliki kemampuan untuk mendidik dan merawat anak untuk dapat tumbuh dan berkembang secara optimal sehingga dapat menciptakan sumber manusia yang berkualitas bagi negara dan masa yang akan datang. Layanan kelas parenting adalah layanan pendukung yang ditunjukan kepada para orang tua atau anggota keluarga yang lain agar memiliki tambahan kemampuan dalam melaksanakan fungsi sosial dan pendidikan dalam hal pengasuhan, perawatan,

17 Djudju Sudjana, Pendidikan Luar Sekolab: Wawasan Sejarah Perkembangan Filsafah dan Teori Pendukung Asas. (Bandung: Falah Production, 2010), 45. 
pendidikan dan pembinaan terhadap anak di rumah, sehingga anak dapat tumbuh dan berkembang secara optimal, sesuai dengan usia dan tahap perkembangannya.

Pendidikan parenting ini bertujuan untuk menyadarkan orang tua, khususnya orang tua muda akan peran dan tanggung jawab atas pengasuhan anak. Pengasuhan anak merupakan tugas yang melekat erat dengan status orang tua.

Secara aplikatif tujuan layanan kelas parenting ini memberikan pemahaman akan bentuk-bentuk dan manfaat keterlibatan orang tua dalam proses dan pengalaman belajar anak.

Sasaran yang akan dicapai oleh PUSPAGA adalah orang tua yang memahami bentuk-bentuk dan manfaat keterlibatannya dalam proses dan pengalaman belajar anaknya. Melalui pemahaman yang diperoleh dari layanan bimbingan tersebut, orang tua diharapkan dapat berpartisipasi dalam proses dan pengalaman belajar anak.

Manfaat yang didapat orang tua dalam mengikuti layanan kelas parenting PUSPAGA, terlebih bagi orang tua muda dalam penelitian ini adalah dapat membangun komunikasi yang baik antara lembaga dengan orangtua. Sehingga pola pengasuhan yang dijalankan di lembaga dengan yang diterapkan orang tua di rumah itu dapat selaras, melalui kegiatan parenting orang tua muda dapat mengetahui pencapaian perkembangan anak, hak-hak dasar yang harus dipenuhi orangtua dalam kelangsungan hidup anak, dan memberikan tambahan pengetahuan kepada orang tua.

Layanan kelas parenting di PUSPAGA dilaksanakan dalam bentuk yaitu kelas orang tua (parenting class) dilaksanakan baik secara formal di ruang seminar. Dalam penyelenggaraan kelas parenting, Orang tua dan pemateri dapat saling berbagi pengalaman dan pengetahuan tentang anak berdasarkan pengetahuan mereka masing-masing. Penyelenggaraan program kelas parenting dibuat dalam bentuk workshop, seminar atau pelatihan tentang pendidikan, perkembangan dan kesehatan anak yang diberikan oleh tenaga ahli PUSPAGA, selain itu penyelenggaraan kelas parenting secara formal dibuat dalam bentuk konsultasi langsung, yakni kesempatan bagi orang tua untuk berkonsultasi dengan tenaga ahli PUSPAGA tentang anaknya. 


\section{Materi Parenting umum yang Disampaikan di Pusat Pembelajaran Keluarga PUSPAGA Surabaya}

Berikut diantara cupikan materi yang didokumentasikan peneliti:

1. Materi Parenting Pola Komunikasi dalam Pola Asuh, pada hari sabtu 4 Mei 2019 oleh Agung Kurniawan, M.Psi., Psikolog

Pola komunikasi yang bisa dibangun orang tua dengan anak bisa dalam lima pilihan di bawah ini:

a. Orang tua Eksesif. Pola ini ditandai dengan sikap orang tua yang marah baik secara verbal atau non verbal. Contoh: " awas, Papa/Mama bisa marah loo"

b. Orang tua otoriter. Pola mendikte dan memberi batasan Contoh: "Ayo! cepetan mandinya, mainanya nanti aja"

c. Orang tua cuek. Orang tua yang membiarkan perilaku anak, saat anak agak mengelak dari perintah orang tua, contoh: " yaa sudah terserah kamu.

d. Orang tua absen. Orang tua bertindak seolah sedang tak ada di samping anak, hal ini terjadi saat orang tua sedang mengalami tekanan, sehingga tak ingin diganggu oleh siapapun. Contoh: "jangan deket Mama/Papa", "sana! sama Papa aja"

e. Orang tua dengan gaya pelatih. Orang tua denga gaya pelatih ini memberi ruang bertanya dan mendengarkan anak terhadap apa yang diinginkan anak dan mendengarkan gagasan anak. Contoh: " kakak ingin apa?"

Dan pola komunikasi yang ideal dalam pola asuh ini adalah yang terakhir, evaluasi kemabli pola komunikasi dengan anak pertahankan yang sudah baik, perbaiki yang belum tepat

2. Materi Parenting pada hari rabu 20 Februari 2019 Menciptakan Pola Asuh Mindfulness oleh Agung Kurniawan, M.Psi., Psikolog.

3. Materi Parenting pada hari rabu 20 Februari 2019 Menjadi Orang Tua Kreatif Dan Inspiratif Dalam Menghadapi Anak Era Millenial oleh Soffy Balgeis, M.Psi., Psikolog. 
4. Materi Parenting pada hari rabu 20 Februari 2019 Seni Komunikasi dalam Keluarga oleh Fatchul Munir, S.Psi., M.PSDM., Psikolog.

Setiap individu itu unik dan berbeda baik dari segi kebiasaan, karakter, dan sifat. Sehingga, diperlukan sebuah komunikasi agar hubungan tercipta secara keterikatan emosi. Komunikasi antar keluarga yang baik akan berjalan secara dua arah. Walau pada kenyataannya komunikasi memang tidak mudah, terkadang ada situasi dan waktu yang kurang tepat atau pesan yang diterima kurang jelas. Kurang efektifnya komunikasi antar pasangan mengakitbatkan muncul masalah terbesar hingga muncul perselisihan dan perceraian. Jadi, perlu diketahui dan diingat oleh masing-masing pasangan bahwa pikiran tidak bisa dibaca, maka sampaikan agar pasangan memahami apa yang kita pikirkan dan rasakan.

Ada tiga isyarat yang menandakan adanya masalah dalam komunikasi, yaitu:

a. Jika terasa tidak alamiah, terasa pura-pura

b. Jika kita dan pasangan tidak nyaman

c. Jika kita tidak merasakan perbaikan pada diri sendiri dan hubungan sesudahnya

agar komunikasi berjalan secara adaptif dan terjalin emotional connected dengan pasangan, Terdapat dua pola komunikasi yang dapat dibangun dengan pasangan, yakni:

a. Komunikasi yang setara (tidak ada yang merasa menang ataupun kalah dalam berkomunikasi)

b. Laki-laki seperti karet gelang dan perempuan seperti ombak (Pria lebih memahami emosi dalam menjaga cintanya dan wanita disadarkan pentingnya menjaga emosi yang naik dan turun ini tetap stabil).

Komunikasi yang efektif dalam memerlukan adanya emotional connected antara suami dan istri. Adapun tips dalam memelihara emotional connected, antara lain:

a. Unconditional love (mencintai tanpa syarat)

b. Movement (mendekat, menjauh, bersama) 
c. Win win communication (komunikasi yang setara, sama-sama menang)

5. Materi Parenting Tiga Keterampilan Dasar Dalam Parenting oleh Fatchul Munir, S.Psi., M.PSDM., Psikolog.

Tiga Keterampilan dasar yang harus dimiliki orang tua dalam memberikan pengasuhan pada anak, agar anak merasa nyaman dan hangat bersama orang tua, yaitu:
a. Menatap Mata
b. Menyentuh Tubuh Anak
c. Ajak Bicara

6. Materi Parenting pada hari Jum`at, 15 februari 2019, Kekompakan Ayah dan Bunda sebagai Kunci Kesuksesan Anak Bicara oleh Fatchul Munir, S.Psi., M.PSDM., Psikolog.

7. Materi Parenting pada hari Jum at, 15 februari 2019, Kiat-kiat Orang Tua Ketika Anak Menjadi Korban Bullying oleh Siti Kamilia, M.Psi., Psikolog dengan materi: Kiat-kiat Orang Tua Ketika Anak Menjadi Korban Bullying

a. Mendengar keluahan tanpa menghakimi : kunci pertama bagi kita orang tua adalah berkenan mendengar keluhan anak, dengarkan semua, tanpa banyak memberi komentar atau bahkan memberi vonis tertentu.

b. Membangun rasa percaya diri: saat di bully kepercayaan diri anak kemungkinan besar akan menurun, sehingga kita orang tua bisa menyampaikan pada anak bahwa mereka berharag, dengan demikian kepercayaan diri anak dapat muncul kembali.

c. Membantu menemukan solusi: selanjutnya yang dapat di lakukan orang tua adalah dengan bersama-sama mencari solusi pemecahan, dengan bersama-sama mengajak anak mencari jalan keluar masalah, maka anak tidak akan merasa sendiri dalam menghadapi permasalahan hidupnya.

Ayo peduli untuk membantu korban bullying yang ada di sekitar kita. Bagi korban bullying, ayo mulai berani atau bersikap atau bersuara, bertindak dan mencari solusi.

8. Materi Parenting pada hari selasa, 22 januari 2019 Problem Soulving dalam Berumah Tangga 
a. Komunikasi : menggunakan kat yang santun daan jelas baik dalam berbicara sehari-hari atau menjelaskan duduk perkara.

b. Mendengarkan : mendengarkan dan memahami apa yang disampaikan lawan biacara (pasangan) dengan seksama dan menghindari persangkaaan pribadi, kemudian memberikan balasan.

c. Mengelola emosi : emosi pada dasarnya ada dua macam: yaitu emosi positif dan negatif, dua macam emosi ini harus dikelola dengan abik agar dapat menyesuaikan diri dengan orang lain di lingkungan sekitar.

d. Keterbukaan : saling terbuka terhadap pasangan untuk meminimalisir salah faham, saling menghargai kebersamaan hidup dengan membentuk hubungan yang saking pengertian dan tibal balik, bisa dengan cara diskusi, membuat kesepakatan bersama, jujur dan komitmen.

Mari terapkan kebiasaan atau budaya baik di dalam lingkup keluarga kita, agar terjalin relasi keluarga yang sehat.

9. Materi Parenting pada hari sabtu, 01 Desember 2018 Pilar-pilar Pengasuhan Positif dalam Mendidik Anak

10. Materi Parenting pada hari selasa, 18 Desember 2019 Cara Orang Tua Melindungi Anak Dari Kekerasan Seksual oleh Rr. Ivonne YS., S.Psi., M.Psi., Psikolog.

1. Kenalkan area yang dilarang dipegang oleh orang lain

2. Sampaikan pesan dengan kata yang jelas dan berulang kali sambil menatap mata anak

3. Dampingi anak saat bermain

Mari kita lakukan edukasi seksual sejak dini dan gunakan istilah sebenarnya agar anak-anak waspada akan keselamatan mereka, selain itu ajarkan konsep privasi bahwa tidak semua orang boleh melihat apalagi menyentuh tubuh mereka, kecuali ibu ayah, dan orang lain setelah diberi izin.

\section{Layanan Parenting di PUSPAGA Perspektif Islam}

Menilik dari penelitian layanan parenting yang dilakukan di PUPAGA, dipandu dengan penjabaran pada kerangka teoritik, dan paparan data pada bab sebelumnya, dalam hal ini peneliti membuat analisis tentang layanan parenting di PUSPAGA perspektif maslahah dalam Hukum Islam, maka sebenarnya layanan parenting yang 
dilakukan PUSPAGA memiliki manfaat yang sangat besar bagi keluarga muda dalam hal memberikan pendidikan keimanan, moral, akal, fisik, psikologis dan sosial.

Pendidikan keimanan menjadi poin utama dalam hal ini, dengan memberikan porsi yang cukup di setiap tahap perkembangan anak, tak hanya berhenti pada waktu perkembangan tertentu, pendidikan keimanan menjadikan anak mengetahui hakikat dirinya dan kewajiban personal yang harus diemban saat anak lahir ke dunia dan kelak dipertanggungjawabkan. Alloh berfirman dalam al-Qur'an surat ad-dariyat: 5618

"dan tidaklah Aku menciptakan jin dan manusia melainkan supaya mereka mengabdi kepada-Ku.

Selain itu mendidik keimanan juga mengenalkan anak akan asal usulnya, siapa panutannya, apa landasan hidupnya dan bagaimana tujuan hidupnya

Selanjutnya memberi pendidikan moral, dalam urutan ini sesungguhnya hanyalah sebuah urutan penjabaran, bukanlah urutan pemberian pendidikan pada prakteknya, karena setiap pendidikan yang harus diberikan pada anak memiliki orientasi yang berbeda dan saling melengkapi keberagaman kompleksitas kehidupan anak. Mengenai pendidikan moral Rosul telah memberi teladan melalu hadis\} dan firman Alloh dalam surat al-Qalam: 4

"sesunggubnya engkau benar-benar berbudi pekerti yang lubur"

Memberi pendidikan moral secara umum adalah bagaimana berperilaku yang santun dan baik. Sedangkan Pendidikan akal yakni mengajarkan pola berfikir yang benar dalam bertidak, berbuat dan belajar, selain itu itu juga memberi pengertian akan fitrah manusia yang berbeda, fitrah alam yang berubah dan lain sebagainya.

Memberikan pendidikan secara fisik pada anak dilakukan bahkan sebelum sang anak lahir ke dunia, dengan memberi kecukupan nutrisi anak sejak dalam kandungan. Sedangkan mendidik psikis dan mental anak, dalam berbagai aspek yang nantinya akan berhubungan erat dengan konsep pendidikan lain. Yang terakhir tak lupa mendidik anak agar dapat survive di lingkungannya dengan baik.

18 Al-Qur`an dan Terjemahnnya, (Kudus: PT. Buya Barokah, T.t). 


\section{Penutup}

Pendidikan parenting di Pusat Pembelajaran Keluarga Surabaya dilakukan dengan model seminar atau training dan konseling kelompok, meliputi pendidikan sosialisasi dengan anak, pola pendidikan moral fisik psikis dan akal anak, serta memberi solusi permasalahan secara aplikatif terhadap permasalahan parenting.

Layanan parenting yang dilakukan di Pusat Pembelajaran Keluarga Surabaya merupakan aplikasi kongkrit dari konsep pendidikan islam yang memberikan kemaslahatan bagi pembentukan keluarga sakinah, mawaddah wa rahmah. Kegiatan ini sekaligus merupakan infestasi masa depan bagi keluarga dan masyarakat dalam rangka membangun ketahanana keluarga di masa yang akan datang.

\section{Daftar Pustaka}

Abdul Fatah Jalal. 1988 .Asas-Asas Pendidikan Islam. Bandung: Diponegoro.

Abdullah Nashih Ulwan,. Tarbiyatul Aulat Fil Islam: Pendidikan Anak Dalam Islam,terjemahan Arif Rahman Hakim .Solo: Insan Kamil. Cet. Ke- 9. 2017.

Abu Muhammad Iqbal. Pemikiran Pendidikan Islam. Yogyakarta: Pustaka Pelajar. 2015.

Ahmad Atabik dan Ahmad Burhanuddin, Konsep Nashib Ulwan Tentang Pendidikan Anak, vol. 3, no. 2, Juli-Desember 2015.

Alwisol. Psikologi Kepribadian, edisi revisi Cet. XII. Malang: UMM Press, 2014

Athiyah al Abrasyi. Al-Tarbiyah al-Islamiyah, terj. Abdullah Zaki alKaaf. Dasar Dasar Pokok Pendidikan Islam. Jakarta: Bulan Bintang. 1970.

Badan Statistik Provinsi Jawa Timur, Statistik Pemuda Provinsi Jawa Timur 2017, BPS Jawa Timur.

Dede Darisman,. Konsep Pendidikan Anak Menurut Abdullah Nashib Ulwan, vol. 9, no. 3. . 2014.

Hasan Langgulung. Beberapa Pemikiran tentang Pendidikan Islam. Jakarta: Pustaka Al-Husna. 1986. 
Hassan Syamsi Basya. Kayfa Turabbi Abna aka fi Hadha al-Zaman, terj. Zaenal Arifin. Mendidik Anak Zaman Kita. Jakarta: Zaman, 2011

Imam Musbikin. Buku Pintar PAUD Tuntunan Praktis Guru PAUD. Jogjakarta: Laksana. 2010.

J. Winardi. Motivasi dan Pemotivasi dalam Manajemen. Jakarta: PT. Raja Grafindo Persada, 2002

Jane Brooks. The Process Of parenting. Yogyakarta: Pustaka Belajar. 2001.

Jarvis Matt, Teori - Teori Psikologi, diterjemahkan dari Theoretical Approaches in Psychology, 2000

Johan Istiadie dan Fauti Subhan, Pendidikan Moral Persfektif Nashib Ulwan, vol. 01, no. 1, Mei 2013.

Lexy Moleong. Metode Penelitian Kualitatif. Bandung : PT. Remaja Rosda karya, 2002

Marc Bornstein,. Handbook of Parenting, Second Edition, 154. 2002.

Melly Kiong. Mindful Parenting. Jakarta: Kemendikbud, 2015

Muhammad Hasan Roqid, Kayfa Nurabbi Abnaana tarbiyatan Solihatan, vol 1

Nahwawi, Abdurrahman Al. Pendidikan Islam di Rumah, Sekolah, dan Masyarakat, Jakarta: Gema Insani. 1995.

Nasution. Metode Research. Jakarta : Bumi Aksara, 2006

Rudi Cahyono. Daily Parenting Menjadikan Orang Tua Pendidik yang Luar Biasa. Jakarta: Pandamedia. 2015.

Saifuddin Azwar. Metode Penelitian. Yogyakarta : Pustaka Pelajar, 2007

Soetrisno Hadi. Metodologi Research. Yogyakarta : Andi Offset, 1994

Sub Direktorat Statistik dan Pendidikan Kesejahteraan Sosial, Statistik Pemuda Indonesia, Jakarta: Badan Pusat Statistik, t.t.

Sugiyono, Memahami Penelitian Kualitatif. Bandung: Alfabeta, 2005

Sugiyono, Metode Penelitian Kuantitatif, Kualitatif Dan R\&D. Bandung: Alfabeta, 2011

Vivian L. Gadsden, Morgan Ford and Heather Briener, T.T. Parenting Matter Supporting Parent Of Children Age 0-8, .Washington, DC: National Academies Press.

Z Hayati. Anak Saya Tidak Nakal. Yogyakarta: PT. Bintang Pustaka, 2010. 